\title{
Impact of the Self-Attribution Bias on the Trading Activity: The Case of the Tunisian Stock Market
}

\author{
Ramzi Boussaidi \\ Dept. of Management, Faculty of Law, Economics and Management of Jendouba \\ University of Jendouba, Tunisia \\ E-mail: boussaidi.ramzi@yahoo.fr
}

Received: December 18, 2016 Accepted: January 05, 2017 Published: January 28, 2017

doi:10.5296/ijafr.v7i1.10640 URL: http://dx.doi.org/10.5296/ijafr.v7i1.10640

\begin{abstract}
The self-attribution bias is the tendency of people to consider themselves as able to influence randomly-generated outcomes. Investors who exhibit such a bias tend to attribute market gains to their ability to select winning stocks and trade actively in the subsequent period. We examined this hypothesis in the Tunisian stock market before and after the 2011 revolution using a causality test between market trading volume and market return. We found that Tunisian investors tend to trade more after observing high market returns and trade less after poor market performance. In the wake of the Tunisian revolution, this effect persists for oneweek horizon, but disappears for one-month horizon.
\end{abstract}

Keywords: Self-attribution, Overconfidence, Trading activity, Tunis Stock Exchange 


\section{Introduction}

The self-attribution bias, also known as "egocentric" or "self-serving attribution" (Miller and Ross, 1975; and Schlenker and Miller, 1977) or "ego-defensive" or beneffectance (Greenwald, 1980), initially took the form of the illusion of control of random events where gains are purely determined by chance as in the case of lottery or coin tosses. This illusion means that people tend to consider themselves as being able to influence randomly-generated outcomes. As a consequence, they tend to attribute their success to their talents and failure to external factors or bad luck. This bias has been documented by, among others, Wolosin, Sherman and Till (1973), Langer (1975), Miller and Ross (1975) and Langer and Roth (1975) through a series of experiments. In financial markets, it has been argued that the selfattribution bias can affect the investors' behavior in the sense that they tend to attribute high market returns or their own portfolio return to their own success.

Since Ross (1989), theoretical and empirical studies have kept arguing that the trading volume on financial markets is too large to be justified in a rational context. Chuang and Lee (2006, p. 2490) noticed that "Trading motivated from hedging and liquidity purposes seems to explain only a small fraction of the observed trading activity and fails to support a substantial amount of trade in the real world". In this regard, several behavioral models were developed to explain the excessive trading volume in stock markets based on overconfidence and self-attribution biases (Daniel, Hirshleifer and Subrahmanyam, 1998, Gervais and Odean, 2001; and Scheinkman and Xiong, 2003). To model the effect of overconfidence on the trading volume, Gervais and Odean (2001) motivate their analysis by the self-attribution bias, wherein overconfident investors mistakenly attribute market gains to their ability to select winner stocks and therefore they excessively trade after observing high market returns.

These models were supported by empirical evidence in different markets all over the world. For example, Statman, Thorley and Vorkink (2006) estimated a bivariate VAR model between monthly market trading volume and monthly market return for 1878 US firms listed on NYSE and AMEX during the period 1962-2002 and found a positive and significant association between the past returns and the current trading volume. Glaser and Weber (2009) adopted diverse regression methodologies (panel data, Tobit model and Logit model) of the monthly trading volume on past returns and other variables such as the number of years of experience, the value of the portfolio held by the investor, his age, and different measures of the trading volume, for 3079 German online investors during the period 1997-2001. They found that past market returns and the past portfolio returns are positively and significantly related to the trading volume. Chuang and Susmel (2011) reported similar results on the Taiwanese stock market for the periods 1996-2007 and 2001-2006, respectively. Further evidence was provided by Griffin, Nardari and Stulz (2007) for 31 out of 46 financial markets during the period 1993-2003 with a prevalent effect in developing markets than in developed ones.

To contribute to the literature on emerging markets, we test in this paper the impact of the self-attribution bias on the trading volume in the Tunisian stock market. The remaining of the paper is organized as follows. Section 2 presents the research design. Section 3 describes the 


\section{Mll Macrothink}

International Journal of Accounting and Financial Reporting

ISSN 2162-3082

2017, Vol. 7, No. 1

data. Section 4 presents the descriptive statistics and performs the unit root tests. Section 5 analyses our empirical results. Section 6 concludes the paper.

\section{Empirical Methodology}

\subsection{The Self-Attribution/Trading Activity Hypothesis}

Gervais and Odean (2001) argue that investors who attribute returns from a general increase in the market to their own talents of selecting securities and processing information become overconfident and therefore trade more actively. As a result, periods of market increases tend to be followed by a period of increase in aggregate trading volume. Similarly to Chuang and Lee (2006), the hypothesis of self-attribution/trading volume can be stated as follows:

"Market gains (losses) make self-attribution-victim investors trade more (less) aggressively in subsequent period."

This hypothesis assumes a one-direction-positive causality from market returns to trading volume.

During the post-revolution period, the Tunisian economy suffered very slow or even negative growth especially during the first years. In fact, after the 2011 Tunisian revolution, the country has experienced political and security instability. This period was marked by a panic among investors who carried out massive sales operations. The selling pressure had a considerable negative effect on the stock market, thus causing a continued decline in the TUNINDEX. We, then, expect that the overconfidence of the Tunisian investors will either be dramatically reduced or will fade away during the post-period revolution due to the unfavorable economic climate.

\subsection{The Model}

To test the relationship between stock returns and trading volume, we refer to Chuang and Lee (2006) who suggested the following model:

$$
\left\{\begin{array}{l}
V_{t}=\alpha_{11}+\alpha_{12}\left|R_{t}\right|+\alpha_{13} M A D_{t}+\sum_{j=1}^{p} \beta_{11 j} V_{t-j}+\sum_{j=1}^{p} \beta_{12 j} R_{t-j}+\varepsilon_{1 t} \\
R_{t}=\alpha_{21}+\alpha_{22} M A D_{t}+\sum_{j=1}^{p} \beta_{21 j} V_{t-j}+\sum_{j=1}^{p} \beta_{22 j} R_{t-j}+\varepsilon_{2 t}
\end{array}\right.
$$

Where $V_{t}$ is the trading volume; $R_{t}$, market-wide return and $M A D_{t}$, Mean absolute cross sectional return deviation. $\left|R_{t}\right|$ and $M A D_{t}$ are used as control variables.

To estimate this model we use the Seemingly Unrelated Regressions method of Zellner (1962). The lag $p$ is determined using the Schwarz information criterion.

\subsection{Construction of the Variables}

To test the self-attribution/trading activity hypothesis in the Tunisian market we consider 


\section{Macrothink \\ International Journal of Accounting and Financial Reporting \\ ISSN 2162-3082 2017, Vol. 7, No. 1}

weekly and monthly observations.

\subsubsection{Market Return}

The continuously compounded weekly return of a security $i$ is the natural logarithm of the Wednesday closing price adjusted for dividends to the previous Wednesday stock price. Similarly, monthly return of a stock $i$ is the natural logarithm of the end of month $t$ stock price adjusted for dividends to the end of month $t-1$ stock price. Market return is the valueweighted stock return in week or month $t$ where the weight of stock $i$ is the stock market capitalization (number of shares outstanding times stock price) to the total market capitalization.

\subsubsection{Trading Volume}

The trading volume is measured by the turnover as the number of shares traded divided by the number of shares outstanding. The weekly turnover of a security is computed according to Lo and Wang (2000) as the sum of daily turnovers from Thursday to the following Wednesday. The monthly turnover of a security is the sum of daily turnovers of month $t$. To aggregate turnover, we compute the value-weighted turnover.

\subsubsection{Mean absolute cross sectional return deviation}

Mean absolute cross sectional return deviation is computed as follows:

$M A D_{t}=\sum_{i=1}^{N} \omega_{i}\left|R_{i t}-R_{t}\right|$

Where, $R_{i t}$ is the return on stock $i$ at time $t ; \omega_{\mathrm{i}}$ is the weight of stock $i$; and $\mathrm{N}$ the number of stocks composing our sample at time $t$.

\section{Data}

Our data consist of the daily closing price, the daily trading volume, the number of shares outstanding and the dividend of all firms listed in the Tunis stock exchange ${ }^{\mathrm{i}}$ from January 1 , 2006 to December 31, 2015. The number of firms increased from 50 at year-end 2006 to 80 at year-end 2015 (Table 1). Daily data are converted to weekly and monthly data as described above. We avoid daily and intraday observations due to the discontinuity problem in such data for some securities in the Tunisian context. To explore the effect of the 2011 Tunisian revolution on the investors' behavior, we divide our full sample period into two sub-periods: 2006-2010 and 2011-2015.

Table 1: Number of firms listed in the Tunis Stock Exchange

\begin{tabular}{|l|l|l|l|l|l|l|l|l|l|l|}
\hline Year & 2006 & 2007 & 2008 & 2009 & 2010 & 2011 & 2012 & 2013 & 2014 & 2015 \\
\hline Nbr. of firms & 50 & 52 & 51 & 53 & 57 & 59 & 60 & 68 & 76 & 80 \\
\hline
\end{tabular}

Note. The table displays the end of year number of firms. 


\section{Descriptive Statistics and Unit Root Tests}

Table 2 displays the descriptive statistics of the weekly (Panel A) and monthly (Panel B) return, turnover and MAD variables for the full sample period and the two sub-periods. The mean weekly return is $0.01 \%$ for the full sample period $2006-2015$ and $0.09 \%$ for the subperiod 2006-2010; however it's negative (-0.07\%) for the post-revolution period 2011-2015.

Table 2: Descriptive Statistics

\section{Panel A. Weekly observations}

\begin{tabular}{|l|l|l|l|l|l|l|l|l|l|}
\hline & \multicolumn{3}{|l}{ Full sample period: 2006-2015 } & \multicolumn{3}{l|}{ Sub-period: 2006-2010 } & \multicolumn{3}{l|}{ Sub-period: 2011-2015 } \\
\hline & $\mathrm{R}$ & $\mathrm{V}$ & $\mathrm{MAD}$ & $\mathrm{R}$ & $\mathrm{V}$ & $\mathrm{MAD}$ & $\mathrm{R}$ & $\mathrm{V}$ & MAD \\
\hline Mean & 0.0001 & 0.0026 & 0.0231 & 0.0009 & 0.0031 & 0.0264 & -0.0007 & 0.0021 & 0.0198 \\
\hline Median & 0.0016 & 0.0021 & 0.0190 & 0.0039 & 0.0026 & 0.0198 & 0.0000 & 0.0017 & 0.0183 \\
\hline Maximum & 0.0814 & 0.0237 & 0.3739 & 0.0814 & 0.0237 & 0.3739 & 0.0766 & 0.0171 & 0.0856 \\
\hline Minimum & -0.2139 & 0.0001 & 0.0070 & -0.2139 & 0.0005 & 0.0075 & -0.0911 & 0.0001 & 0.0070 \\
\hline Std. Dev. & 0.0217 & 0.0021 & 0.0262 & 0.0263 & 0.0023 & 0.0357 & 0.0158 & 0.0017 & 0.0085 \\
\hline Skewness & -3.6886 & 4.3933 & 10.158 & -4.0456 & 4.0876 & 7.7033 & -0.7025 & 5.2981 & 2.9239 \\
\hline Kurtosis & 35.737 & 33.768 & 125.76 & 32.077 & 30.056 & 69.787 & 11.682 & 44.276 & 18.698 \\
\hline Prob (J-B) & 0.0000 & 0.0000 & 0.0000 & 0.0000 & 0.0000 & 0.0000 & 0.0000 & 0.0000 & 0.0000 \\
\hline Obs. & 520 & 520 & 520 & 261 & 261 & 261 & 259 & 259 & 259 \\
\hline Panel B. M & & & & & & & &
\end{tabular}

Panel B. Monthly observations

\begin{tabular}{|l|l|l|l|l|l|l|l|l|l|}
\hline Mean & 0.0002 & 0.0109 & 0.0539 & 0.0036 & 0.0131 & 0.0650 & -0.0032 & 0.0088 & 0.0427 \\
\hline Median & 0.0041 & 0.0097 & 0.0431 & 0.0122 & 0.0118 & 0.0458 & -0.0029 & 0.0080 & 0.0395 \\
\hline Maximum & 0.0894 & 0.0326 & 0.3780 & 0.0894 & 0.0326 & 0.3780 & 0.0602 & 0.0217 & 0.0991 \\
\hline Minimum & -0.2354 & 0.0026 & 0.0192 & -0.2354 & 0.0038 & 0.0215 & -0.1299 & 0.0026 & 0.0192 \\
\hline Std. Dev. & 0.0478 & 0.0053 & 0.0465 & 0.0585 & 0.0055 & 0.0626 & 0.0339 & 0.0041 & 0.0138 \\
\hline Skewness & -1.6039 & 0.9420 & 5.090 & -1.7512 & 0.7175 & 3.6959 & -0.6626 & 1.1308 & 1.8063 \\
\hline Kurtosis & 8.6185 & 4.1287 & 33.066 & 7.5720 & 4.0272 & 17.624 & 4.8100 & 4.2528 & 8.0901 \\
\hline Prob (J-B) & 0.0000 & 0.0000 & 0.0000 & 0.0000 & 0.0204 & 0.0000 & 0.0019 & 0.0002 & 0.0000 \\
\hline Obs. & 120 & 120 & 120 & 60 & 60 & 60 & 60 & 60 & 60 \\
\hline
\end{tabular}

Notes: J-B is the Jarque-Béra statistic; Obs. is the number of observations

For monthly observations, it's $0.02 \%, 0.36 \%$ and $-0.32 \%$, respectively. The poor stock market performance during the post-revolution period reflects the poor performance of the Tunisian economy during that period. However, the mean weekly turnover has slightly decreased from 0.0031 for the sub-period 2006-2010 to 0.0021 for the sub-period 2011-2015. The monthly turnover has decreased from 0.0131 to 0.0088 , respectively. Based on the standard deviation, we note that the returns during the second sub-period are less volatile than the returns during the first sub-period. The probability of Jarque-Béra is less than 5\% indicating that the null hypothesis of normality is rejected. Therefore, our series are not normally distributed. 


\section{Mll Macrothink}

International Journal of Accounting and Financial Reporting ISSN 2162-3082 2017, Vol. 7, No. 1

To check the stationarity of the series we use the Augmented Dickey-Fuller test (Dickey and Fuller, 1981). This test is based on three models: a model with a constant and a trend (model 3 ), a model with a constant (model 2) and a model without constant and trend (model 1). To choose the appropriate model we will adopt a simple sequential strategy that begins with model 3 and applies a joint test of the trend significance. If the trend is significantly different from 0 , then model 3 should be adopted to judge the stationarity of the series. If not, we move to model 2. If the constant is significant, we use this model; otherwise, we consider model 1.When no lag is significant in ADF models, a simple DF test is appropriate.

Table 3 shows that the DF statistic is less than the critical values (or similarly, the probability of DF statistic is lower than 1\%) for all the variables during the full-sample period and the sub-periods in weekly or monthly frequency. The null of unit root in the series is rejected. R, $\mathrm{V}$ and MAD are therefore stationary in level.

Table 3: Unit Root Test

\begin{tabular}{|c|c|c|c|c|c|c|c|c|c|c|c|c|}
\hline \multirow[b]{3}{*}{ Periods } & \multicolumn{6}{|c|}{ Weekly observations } & \multicolumn{6}{|c|}{ Monthly observations } \\
\hline & \multicolumn{2}{|l|}{$\mathrm{R}$} & \multicolumn{2}{|l|}{ V } & \multicolumn{2}{|c|}{ MAD } & \multicolumn{2}{|l|}{$\mathrm{R}$} & \multicolumn{2}{|l|}{$\mathrm{V}$} & \multicolumn{2}{|c|}{ MAD } \\
\hline & M & DF stat & M & DF stat & M & DF stat & M & DF stat & M & DF stat & M & DF stat \\
\hline $\begin{array}{l}\text { Full sample period } \\
2006-2015\end{array}$ & 1 & $\begin{array}{l}-22.306 \\
(0.000)\end{array}$ & 3 & $\begin{array}{l}-19.466 \\
(0.000)\end{array}$ & 3 & $\begin{array}{l}-22.501 \\
(0.000)\end{array}$ & 1 & $\begin{array}{l}-9.707 \\
(0.000)\end{array}$ & 3 & $\begin{array}{l}-9.301 \\
(0.000)\end{array}$ & 3 & $\begin{array}{l}-11.382 \\
(0.000)\end{array}$ \\
\hline $\begin{array}{l}\text { Sub-period } \\
2006-2010\end{array}$ & 1 & $\begin{array}{l}-15.518 \\
(0.000)\end{array}$ & 2 & $\begin{array}{l}-14.12 \\
(0.000)\end{array}$ & 2 & $\begin{array}{l}-16.117 \\
(0.000)\end{array}$ & 1 & \begin{tabular}{|l|}
-7.066 \\
$(0.000)$
\end{tabular} & 1 & $\begin{array}{l}-7.174 \\
(0.000)\end{array}$ & 2 & $\begin{array}{l}-7.954 \\
(0.000)\end{array}$ \\
\hline $\begin{array}{l}\text { Sub-period } \\
2011-2015\end{array}$ & 1 & $\begin{array}{l}-13.223 \\
(0.000)\end{array}$ & 2 & $\begin{array}{l}-13.791 \\
(0.000)\end{array}$ & 2 & $\begin{array}{l}-11.616 \\
(0.000)\end{array}$ & 1 & $\begin{array}{l}-3.158 \\
(0.002)\end{array}$ & 2 & $\begin{array}{l}-6.323 \\
(0.000)\end{array}$ & 2 & $\begin{array}{l}-7.417 \\
(0.000)\end{array}$ \\
\hline
\end{tabular}

Notes: The null hypothesis is that the series has a unit root. Numbers in parentheses are probabilities corresponding to the Dickey-Fuller statistic. $\mathrm{M}$ is the model considered to check the stationarity of the series. Critical values are -2.60 (at $1 \%$ level) $;-1.95(5 \%)$; and -1.61 $(10 \%)$ for model $1 ;-3.51 ;-2.89$ and -2.58 for model 2 ; and $-4.04 ;-3.45$ and -3.15 for model 3 , respectively

\section{Empirical Results}

The model (1) estimation results are summarized in table 4. Panel A displays the results corresponding to weekly observations. For the full-sample period, the optimal lag, determined by the Schwartz criterion, is equal to 3. First, the null that the lagged return coefficients are jointly equal to zero $\left(\beta_{121}=0 ; \beta_{122}=0\right.$ and $\left.\beta_{12}{ }_{3}=0\right)$ is rejected at the $5 \%$ level

(the p-value corresponding to the $\chi_{1}^{2}$ is 0.024 , less than $5 \%$ ). This means that we reject the null that $R$ does not Granger cause $V$ at the 5\% level. Second, the sum of the lagged return coefficients is positive $\left(\beta_{121}+\beta_{12}+\beta_{12}=0.0206\right)$ and significantly different from zero at the $5 \%$ level ( $\mathrm{p}$-value $=0.005$ ) which indicates a positive cumulative effect of past weekly returns on current trading volume. Third, the lagged volume coefficients in the second equation $\left(\beta_{21} ; \beta_{21}\right.$ and $\left.\beta_{213}=0\right)$ are not jointly significant indicating that we cannot reject the null that $V$ does not Granger-cause $R$. This means that there is no causality arising from 


\section{Macrothink}

International Journal of Accounting and Financial Reporting ISSN 2162-3082 2017, Vol. 7, No. 1

the weekly trading volume to the weekly return. This implies that there is a one-directional positive causality from the weekly return to the weekly trading volume. Consistently with the self-attribution hypothesis, this finding suggests that past high market returns over the past three weeks incite overconfident investors to trade more actively in the following week. However, past low or negative market returns over the past three weeks causes a decrease in trading volume over the following week. Similar results (available on request) are found for different lags ranging from 1 to 12 weeks. For the two sub-periods, the null that $\mathrm{R}$ does not Granger-cause $\mathrm{V}$ is rejected at $10 \%$ level. The positive cumulative effect of lagged returns on trading volume is significant at 5\% level for the pre-revolution sub-period 2006-2010 and $10 \%$ for the post-revolution sub-period 2011-2015. This implies that the selfattribution/trading activity hypothesis holds for the two sub-periods.

Our findings are consistent with those of Chuang and Lee (2006) in the U.S market, Glaser and Weber (2009) in Germany and Chuang and Susmel (2011) in Taiwan. Furthermore, in their sample of 46 markets, Griffin et al. (2007) considered 20 emerging markets which do not include the Tunisian market. Our findings, therefore, add to the evidence found by the authors.

With monthly observations (Panel B), the optimal lag is equal to 1 for the full-sample period and the two sub-periods. In order to explore the cumulative effect of past returns on current volume we extend the lag $p$ to three months (Panel C). We find that the self-attribution hypothesis holds for the full-sample and the pre-revolution sub-period but it is rejected for the post-revolution period. For the post-revolution period, the self-attribution bias exists in the very short term (one week) but it disappears for one-month horizon. This indicates that the Tunis stock exchange is able to "cure" itself from such anomaly in period of crisis. Furthermore, although they exhibit overconfidence in short term, investors lose confidence for one-month horizon and become rational.

\section{Conclusion}

The self-attribution, one of the facets of the overconfidence bias, refers to the fact that investors attribute market gains to their own talent and losses to bad luck. As a consequence, their trading activity depends on the past market returns. We examined this bias in the Tunisian stock market using a causality test between market trading volume and market return for the period 2006-2015. Our results indicate that Tunisian investors tend to increase their trading volume after observing high market returns and reduce their trading volume after poor market performance. After the Tunisian revolution, this effect persists in the very short term (for weekly observations), but it fades away for one-month horizon indicating that in period of crisis, Tunisian investors lose confidence and become rational. 
Table 4: Causality between Return and Trading Volume

\begin{tabular}{|c|c|c|c|c|c|c|c|c|c|c|c|c|}
\hline \multirow{3}{*}{$\begin{array}{l}\text { Endog. } \\
\text { Exog. }\end{array}$} & \multicolumn{4}{|c|}{ Full sample period 2006-2015 } & \multicolumn{4}{|c|}{ Sub-period 2006-2010 } & \multicolumn{4}{|c|}{ Sub-period 2010-2015 } \\
\hline & \multicolumn{2}{|l|}{$V_{t}$} & \multicolumn{2}{|c|}{$R_{t}$} & \multicolumn{2}{|r|}{ Now perie } & \multicolumn{2}{|l|}{$R_{t}$} & \multicolumn{2}{|l|}{$V_{t}$} & \multicolumn{2}{|c|}{$R_{t}$} \\
\hline & $V_{t-j}$ & $R_{t-j}$ & $V_{t-j}$ & $R_{t-j}$ & $V_{t-j}$ & $R_{t-j}$ & $V_{t-j}$ & $R_{t-j}$ & $V_{t-j}$ & $R_{t-j}$ & $V_{t-j}$ & $R_{t-j}$ \\
\hline \multicolumn{13}{|c|}{ Panel A. Weekly observations } \\
\hline & \multicolumn{4}{|c|}{ Optimal lag 3} & \multicolumn{4}{|c|}{ Optimal lag 2} & \multicolumn{4}{|c|}{ Optimal lag 4} \\
\hline$\chi_{1}^{2}(\mathrm{p}$-value $)$ & $\begin{array}{l}17.435 \\
(0.0006)\end{array}$ & \begin{tabular}{|l}
9.447 \\
$(0.024)$
\end{tabular} & $\begin{array}{l}2.9538 \\
(0.399)\end{array}$ & $\begin{array}{l}5.3420 \\
(0.148)\end{array}$ & $\begin{array}{l}2.6900 \\
(0.261)\end{array}$ & \begin{tabular}{|l|}
4.9267 \\
$(0.085)$
\end{tabular} & $\begin{array}{l}0.1794 \\
(0.914)\end{array}$ & $\begin{array}{l}7.0850 \\
(0.029)\end{array}$ & $\begin{array}{l}4.2667 \\
(0.371)\end{array}$ & $\begin{array}{l}8.0777 \\
(0.089)\end{array}$ & $\begin{array}{l}2.2605 \\
(0.688)\end{array}$ & $\begin{array}{l}24.950 \\
(0.000)\end{array}$ \\
\hline Sum lagged coef. & 0.2614 & 0.0206 & 0.7234 & 0.1302 & 0.1231 & 0.0174 & 0.1542 & 0.1575 & 0.1310 & 0.0276 & 0.7971 & 0.3424 \\
\hline$\chi_{2}^{2}(\mathrm{p}$-value $)$ & $\begin{array}{l}15.325 \\
(0.0001)\end{array}$ & $\begin{array}{l}7.9554 \\
(0.005)\end{array}$ & $\begin{array}{l}1.5871 \\
(0.208)\end{array}$ & $\begin{array}{l}4.4363 \\
(0.035)\end{array}$ & $\begin{array}{l}2.1202 \\
(0.145)\end{array}$ & $\begin{array}{l}4.8932 \\
(0.027)\end{array}$ & $\begin{array}{l}0.0511 \\
(0.821)\end{array}$ & $\begin{array}{l}6.2283 \\
(0.013)\end{array}$ & $\begin{array}{l}1.3460 \\
(0.246)\end{array}$ & $\begin{array}{l}2.9411 \\
(0.086)\end{array}$ & $\begin{array}{l}0.8966 \\
(0.344)\end{array}$ & $\begin{array}{l}8.5610 \\
(0.003)\end{array}$ \\
\hline $\operatorname{Adj} R^{2}$ & \multicolumn{2}{|c|}{0.051} & \multicolumn{2}{|c|}{0.3331} & \multicolumn{2}{|c|}{0.0155} & \multicolumn{2}{|c|}{0.4961} & \multicolumn{2}{|c|}{0.0581} & \multicolumn{2}{|c|}{0.0767} \\
\hline $\mathrm{Q}(6)$ (p-value) & \multicolumn{2}{|c|}{$1.2127(0.976)$} & \multicolumn{2}{|c|}{$10.348(0.111)$} & \multicolumn{2}{|c|}{$1.4177(0.965)$} & \multicolumn{2}{|c|}{$1.9944(0.920)$} & \multicolumn{2}{|c|}{$2.1599(0.904)$} & \multicolumn{2}{|c|}{$3.0840(0.214)$} \\
\hline \multicolumn{13}{|c|}{ Panel B. Monthly observation } \\
\hline & \multicolumn{4}{|c|}{ Optimal lag 1} & \multicolumn{4}{|c|}{ Optimal lag 1} & \multicolumn{4}{|c|}{ Optimal lag 1} \\
\hline$\chi_{1}^{2}(\mathrm{p}$-value $)$ & $\begin{array}{l}4.7633 \\
(0.0291)\end{array}$ & \begin{tabular}{|l|}
11.897 \\
$(0.0006)$
\end{tabular} & $\begin{array}{l}0.1554 \\
(0.693)\end{array}$ & $\begin{array}{l}2.0439 \\
(0.153)\end{array}$ & $\begin{array}{l}4.7633 \\
(0.029)\end{array}$ & $\begin{array}{l}11.897 \\
(0.001)\end{array}$ & $\begin{array}{l}0.1554 \\
(0.693)\end{array}$ & $\begin{array}{l}2.0439 \\
(0.153)\end{array}$ & $\begin{array}{l}1.4323 \\
(0.231)\end{array}$ & $\begin{array}{l}1.9093 \\
(0.167)\end{array}$ & $\begin{array}{l}1.8128 \\
(0.178)\end{array}$ & $\begin{array}{l}1.8336 \\
(0.176)\end{array}$ \\
\hline lagged coef. & 0.1906 & 0.0335 & -0.286 & 0.1149 & 0.1906 & 0.0335 & -0.286 & 0.1149 & 0.1579 & 0.0247 & 1.2772 & 0.1654 \\
\hline$\chi_{2}^{2}(\mathrm{p}$-value $)$ & \begin{tabular}{|l|}
4.7633 \\
$(0.0291)$
\end{tabular} & \begin{tabular}{|l|}
11.897 \\
$(0.0006)$
\end{tabular} & $\begin{array}{l}0.1554 \\
(0.693)\end{array}$ & $\begin{array}{l}2.0439 \\
(0.152)\end{array}$ & $\begin{array}{l}4.7633 \\
(0.029)\end{array}$ & $\begin{array}{l}11.897 \\
(0.001)\end{array}$ & $\begin{array}{l}0.1554 \\
(0.693)\end{array}$ & $\begin{array}{l}2.0439 \\
(0.153)\end{array}$ & $\begin{array}{l}1.4323 \\
(0.231)\end{array}$ & $\begin{array}{l}1.9093 \\
(0.167)\end{array}$ & $\begin{array}{l}1.8128 \\
(0.178)\end{array}$ & $\begin{array}{l}1.8336 \\
(0.176)\end{array}$ \\
\hline $\operatorname{Adj} R^{2}$ & \multicolumn{2}{|c|}{0.1272} & & 557 & & 272 & & 557 & & 338 & & 318 \\
\hline $\mathrm{Q}(6)$ (p-value) & 3.414 & $(0.332)$ & 4.315 & $(0.634)$ & 5.772 & $(0.449)$ & 8.187 & $(0.225)$ & 2.414 & $(0.878)$ & 7.922 & $(0.244)$ \\
\hline & & & & & & & & & & & g 3 & \\
\hline$\chi_{I}^{2}(\mathrm{p}$-value $)$ & $\begin{array}{l}8.1953 \\
(0.042)\end{array}$ & \begin{tabular}{|l|}
12.439 \\
$(0.006)$
\end{tabular} & $\begin{array}{l}0.4098 \\
(0.938)\end{array}$ & $\begin{array}{l}1.9238 \\
(0.588)\end{array}$ & $\begin{array}{l}0.4718 \\
(0.925)\end{array}$ & $\begin{array}{l}10.2064 \\
(0.017)\end{array}$ & \begin{tabular}{|l|}
3.4757 \\
$(0.324)$
\end{tabular} & \begin{tabular}{|l|}
1.5175 \\
$(0.678)$
\end{tabular} & $\begin{array}{l}1.6065 \\
(0.658)\end{array}$ & \begin{tabular}{|l|}
0.9294 \\
$(0.818)$
\end{tabular} & $\begin{array}{l}9.7329 \\
(0.021)\end{array}$ & $\begin{array}{l}6.8354 \\
(0.077)\end{array}$ \\
\hline Sum lagged coef. & 0.3832 & 0.0327 & -0.116 & 0.1513 & 0.0558 & 0.0365 & -2.547 & 0.1159 & 0.1891 & 0.0191 & -1.873 & 0.3838 \\
\hline$\chi_{2}^{2}(\mathrm{p}$-value $)$ & $\begin{array}{l}8.1260 \\
(0.004)\end{array}$ & \begin{tabular}{|l|}
3.9484 \\
$(0.047)$
\end{tabular} & $\begin{array}{l}0.0107 \\
(0.918)\end{array}$ & $\begin{array}{l}1.2240 \\
(0.269)\end{array}$ & $\begin{array}{l}0.0526 \\
(0.819)\end{array}$ & $\begin{array}{l}2.9268 \\
(0.087)\end{array}$ & $\begin{array}{l}1.5132 \\
(0.219)\end{array}$ & $\begin{array}{l}0.4067 \\
(0.524)\end{array}$ & $\begin{array}{l}0.6066 \\
(0.436)\end{array}$ & $\begin{array}{l}0.2886 \\
(0.591)\end{array}$ & $\begin{array}{l}1.7756 \\
(0.183)\end{array}$ & $\begin{array}{l}3.6673 \\
(0.056)\end{array}$ \\
\hline $\operatorname{Adj} R^{2}$ & & 312 & & & & 547 & & 874 & & 042 & & 849 \\
\hline $\mathrm{Q}(6)$ (p-value) & 5.023 & $(0.541)$ & 4.275 & $(0.639)$ & 3.828 & $(0.700)$ & 8.707 & $(0.191)$ & 2.308 & $(0.889)$ & 6.861 & $(0.334)$ \\
\hline
\end{tabular}

Notes: The $\chi_{1}^{2}$ statistic is a joint test of the null hypothesis that the lagged coefficients are equal to zero. The $\chi_{2}^{2}$ test statistic is used to test the null hypothesis that the sum of the estimated lagged coefficients is equal to zero. Q(6) is the Ljung-Box Q-statistic. 


\section{Macrothink}

\section{Acknowledgement}

The author would like to thank Mohamed Chaker Chafaï, Noureddine Aridhi and two anonymous referees for their helpful comments and suggestions.

\section{References}

Boussaidi, R. \& Abaoub, E. (2016), "The dynamics of Stock price adjustment to fundamentals: an empirical essay via STAR models in the Tunisian stock market", Economics Bulletin, Vol. 36, No. 2, pp. 813-826.

Chuang W. I. \& B. S. Lee (2006), "An empirical evaluation of the overconfidence hypothesis", Journal of Banking and Finance, Vol. 30, No. 9, pp. 2489-2515.

Chuang W. I. \& R. Susmel (2011), "Who is the more overconfident trader? Individual vs. institutional investors", Journal of Banking and Finance, Vol. 35, No. 7, pp. 1626-1644.

Daniel K., D. Hirshleifer \& A. Subrahmanyam (1998), "Investor psychology and security market under and overreactions”, Journal of Finance, Vol. 53, No. 6, pp. 1839-1885.

Gervais S. \& T. Odean (2001), "Learning to Be Overconfident", The Review of Financial Studies, Vol. 14, No. 1, pp. 1-27.

Glaser M. \& M. Weber (2009), "Which past returns affect trading volume?", Journal of Financial Markets, Vol. 12, pp. 1-31.

Greenwald A. G. (1980), "The totalitarian ego fabrication and revision of personal history", American Psychologist, Vol. 35, No. 7, pp. 603-618.

Langer E. J. (1975), "The illusion of control", Journal of Personality and Social Psychology, Vol. 32, pp. 311-329.

Langer I. J. \& J. Roth (1975), "Heads I Win, Tails It's Chance: The Illusion of Control as a Function of the Sequence of Outcomes in a Purely Chance Task", Journal of Personality and Social Psychology, Vol. 32, No. 6, pp. 951-955.

Lo A.W. \& J. Wang (2000), “Trading Volume: definitions, data analysis, and implications of portfolio theory”, Review of Financial Studies, Vol. 13, pp. 527-300.

Miller D., \& M. Ross (1975), "Self-serving Biases in Attribution of Causality: Fact or Fiction?" Psychological Bulletin, Vol. 82, pp. 213-225.

Ross S. (1989), "Information and volatility: The no-arbitrage martingale approach to timing and resolution irrelevancy", Journal of Finance, Vol. 44, 1-17.

Scheinkman J. A \& W. Xiong (2003), "Overconfidence and speculative bubbles", Journal of political Economy, Vol. 111, pp. 1183-1219.

Schlenker B. R., \& R. S. Miller (1977), "Egocentrism in groups: Self-serving biases or logical information processing?”, Journal of Personality and Social Psychology, Vol. 35, pp. 755-764. 


\section{Macrothink}

International Journal of Accounting and Financial Reporting ISSN 2162-3082

Statman M., S. Thorley \& K. Vorkink (2006), "Investor overconfidence and trading volume", Review of Financial Studies, Vol. 19, No. 4, pp. 1531-1565.

Wolosin R. J., S. J. Sherman \& A. Till (1973), "Effects of cooperation and competition on responsibility attribution after success and failure", Journal of Experimental Social Psychology, Vol. 9, pp. 220-235.

Zellner A. (1962), “An Efficient Method of Estimating Seemingly Unrelated Regressions and Tests for Aggregation Bias", Journal of the American Statistical Association, Vol. 57, No. 298, pp. 348- 368.

\section{Copyright Disclaimer}

Copyright for this article is retained by the author(s), with first publication rights granted to the journal.

This is an open-access article distributed under the terms and conditions of the Creative Commons Attribution license (http://creativecommons.org/licenses/by/3.0/).

\footnotetext{
'For a brief description of the Tunis Stock Exchange, the reader can refer to Boussaidi and Abaoub (2016).
} 